\title{
IKAN HIAS AIR TAWAR EKSPOR INDONESIA
}

\author{
Darti Satyani dan I Wayan Subamia \\ Loka Riset Budidaya Ikan Hias Air Tawar \\ Jl. Perikanan No. 13, Pancoran Mas, Depok 16436 \\ E-mail: Irbihat@dkp.co.id
}

\begin{abstract}
ABSTRAK
Spesies ikan hias air tawar dari Indonesia yang diekspor oleh para eksportir terutama dari daerah Jabo detabek sangat banyak. Pasar ekspor merupakan pasar terbesar untuk ikan hias Indonesia. Negara tujuan ekspor hampir ke seluruh dunia, mulai dari Eropa, Amerika, Australia, Jepang, China, Hongkong, Singapura bahkan Timur Tengah seperti Iran dan Arab Saudi. Nilai ekspor yang tercatat pada tahun 2000 masih sekitar 4 juta dollar namun tahun 2003 sudah mencapai sekitar 15 juta dollar US versi Badan Pengembangan Ekspor Nasional, dan tahun 2006 sudah dicapai 130 juta dollar US. Walaupun demikian menurut versi BPEN pula Indonesia baru mengisi 9\%pasar di Eropa dan 6\%ke Amerika, sementara Singapura mengisi 25\% dan 30\%nya. Ikan ekspor ini terdiri atas spesiesspesies ikan yang berasal dari perairan Indonesia sendiri dan ikan introduksi dari perairan negara lain seperti Amerika Selatan, Afrika, dan Asia Tenggara lainnya. Produk didapatkan dari hasil tangkapan alam maupun dari hasil budidaya. Beberapa merupakan ikan yang di re-ekspor dari negara asal ke negara pengimpor. Data jenis ikan yang telah dibuat dalam bentuk tabulasi didasarkan dari asal ikan didapatkan dari list beberapa eksportir yang berada di daerah Jakarta, Bogor, Bekasi, dan Depok. Dari data tersebut ternyata ikan asli perairan Indonesia masih banyak yang diambil dari alam (tangkapan), dan ikan introduksi yang masuk dan dibudidayakan disini justru lebih banyak.
\end{abstract}

KATAKUNC: ikan hias, list jenis, alam, introduksi

\section{PENDAHULUAN}

Perdagangan ikan hias air tawar saat ini sudah merupakan bisnis yang besar dan mendunia. Adanya Aquarama yang digelar setiap 2 (dua) tahun dan dikunjungi baik hobiis dan pebisnis di seluruh dunia menandakan hal ini. Selain ikannya sendiri aksesoris akuarium juga sudah menelurkan industri yang tidak dapat dianggap kecil. Kenyataan ini sebenarnya dapat memberikan pemacu bagi negara kita untuk ambil bagian yang lebih besar dalam perdagangan ini, mengingat sumberdaya ikan hias kita yang sangat besar.

Pasar dunia ikan hias amat besar dan luas. Permintaan akan komoditas ini terus meningkat baik dari jumlah maupun jenisnya terutama pasar ekspor. Jenis baru baik yang asli maupun silangan terus bermunculan dari berbagai pelosok dunia. Indonesia termasuk negara yang kaya akan sumberdaya ikan hias setelah Amerika Selatan. Jumlah spesies ikan hias yang lebih dari 300 jenis sebanyak 34\%nya berada di Indonesia.(Sakurai et al., 1995 dalam Aquarium of the World).

Produksi ikan hias air tawar di Indonesia selain dari budidaya juga dari tangkapan alam. Penelusuran yang dilakukan terhadap para eksportir dari daerah Jakarta dan sekitarnya didapatkan banyak spesies ikan yang mereka datangkan dari perairan umum terutama luar Jawa, Sumatera, dan Kalimantan merupakan daerah yang banyak diambil ikannya karena mungkin dekat dengan Jakarta dan memang daerah ini merupakan daerah yang kaya akan spesies ikannya. Ikan-ikan introduksi juga cukup banyak yang diperdagangkan, bahkan sebagian besar sudah banyak dibudidayakan terutama di daerah Jabodetabek.

Dari data yang didapatkan maka baru sekitar 30\%dari jenis ikan asli yang diekspor sudah atau dapat dibudidayakan, sementara sekitar 70\%nya masih ditangkap dari perairan aslinya atau dari alam. Apabila ini terus berlanjut maka tentu amat disayangkan karena selain sumberdaya ikan ini tentunya akan makin habis, sehingga devisa yang adapun akan menurun. Ditambah lagi hilangnya khasanah fauna ini akan punah dan anak cucu pun kehilangan plasma nutfah yang berharga. Sementara ikan introduksi malah sebaliknya jenis yang sudah dibudidayakan hampir $80 \%$ jauh lebih banyak daripada yang belum.

\section{PERDAGANGAN IKAN HIAS AIR TAWAR}

Pasar ekspor merupakan pasar terbesar untuk ikan hias Indonesia. Negara tujuan ekspor hampir ke seluruh dunia, mulai dari Eropa, Amerika, Australia, Jepang, Cina, Hongkong, Singapura bahkan saat ini sampai ke Timur Tengah seperti Iran dan Arab Saudi. Pasar ekspor ikan 
hias ini juga meningkat dari tahun ke tahun. Nilai ekspor yang tercatat pada tahun 2000 masih sekitar 4 juta dollar namun tahun 2003 sudah mencapai sekitar 15 juta dollar US versi Badan Pengembangan Ekspor Nasional, dan tahun 2006 sudah dicapai 130 juta dollar US. Kenaikan jumlah yang cukup signifikan. Walaupun demikian menurut versi BPEN pula Indonesia baru mengisi 9\%pasar di Eropa dan $6 \%$ ke Amerika, sementara Singapura mengisi 25\%dan $30 \%$ nya. Perbandingan ini masih amat jauh, padahal ikan Singapura berasal dari Indonesia.

\section{IKAN HIAS ALAM UNTUK EKSPOR}

Sampai saat ini, tahun 2009 tercatat ada lebih dari seratus jenis ikan tangkapan alam yang diekspor melalui beberapa eksportir yang ada di Jakarta. Ikan-ikan ini berasal dari perairan Sumatera, khususnya selatan, Kalimantan, Sulawesi maupun Irian. Jawa daerah pesisir selatan masih ada walaupun sedikit.

Ikan-ikan ini didatangkan setiap musim dengan jumlah yang tak terbatas. Pengumpul dari daerah berusaha mengumpulkan ikan dari penangkap sebanyakbanyaknya karena seberapapun banyak akan ditampung di penampungan. Saat musim inilah harga ikan menjadi turun atau murah. Dengan demikian sebenarnya yang paling diuntungkan tentu pedagang.

Pemintaan pasar yang terus meningkat menjadikan orang menangkap ikan besar-besaran. Ikan yang ditangkap dalam jumlah yang banyak dan dalam penampungan yang terlalu padat akan menimbulkan banyak kematian. Persentase dari hasil tangkapan dan yang terjual yaitu yang hidup sebenarnya amatlah tidak seimbang. Banyak ikan mati sia-sia baik dalam penampungan serta selama transportasi dan menjadi tidak bernilai.

Ikan yang dianggap tidak ekonomis saat itu dibuang dan mati ditempat penampungan, padahal di masa mendatang ikan tersebut akan berharga. Sebagai contoh ikan julung-julung bahkan siput dan udang kali atau udang kecil yang dulu tidak ada harganya sekarang juga diperdagangkan sebagai ikan hias.

Informasi dan data yang diambil dari list beberapa eksportir di daerah Jabodetabek (Tabel1 dan Tabel Lampiran 1) didapatkan ada 141 jenis ikan hias air tawar alam yang saat ini masuk dalam daftar ekspor mereka. Ikan didatangkan saat musim tangkapan dan akan ditampung untuk di ekspor ke negara pengimpor dalam jumlah dan waktu sesuai permintaan.

Dari ratusan jenis yang terdaftar saat ini beberapajenis makin sulit didapatkan atau jarang ada. Sebagai contoh ikan Rasbora, menurut para eksportir sudah mulai banyak berkurang di alamnya. Botia Sumatera juga sudah sangat sedikit. Berbagai jenis malah sudah mulai punah dan sudah jarang ditemukan lagi. Ikan blackshark, balashark, dan beberapa jenis puntius sudah banyak yang tidak ada lagi di list para eksportir.

Dari Familia Anabantidae ikan Betta atau cupang merupakan yang terpopuler. Adanya kontes dan klub-klub Betta baik lokal maupun internasional membuat ikan ini sangat digemari. Walaupun hasil budidaya sudah banyak dengan varitas yang cantik-cantik tetapi cupang alam tetap banyak diminati dan harganya cukup tinggi, membuat ikan ini selalu digemari. Demikian pula ikan sepat batik (Sphaerichthys sp.) yang warnanya sangat cantik ini cukup banyak permintaannya. Ikan ini sangat rentan dan mudah sakit sehingga kematian dalam penampungan cukup tinggi. Sepat mutiara, biru (Trichogaster sp.) juga ada dalam list ekspor, namun ikan ini sudah banyak yang membudidayakan sehingga tidak semuanya mengandalkan dari tangkapan alam.

Dari Familia Bagridae, Balitoridae, Chandidae maupun Channidae belum ada satu jenispun yang dibudidayakan, sehingga semua masih diambil dari alam. Ikan Chanda

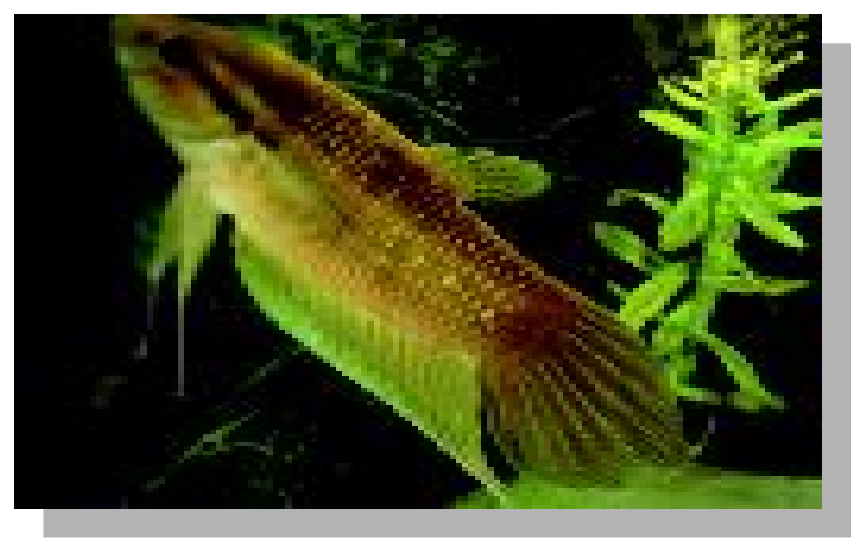

Cupang alam (Betta pugnax)

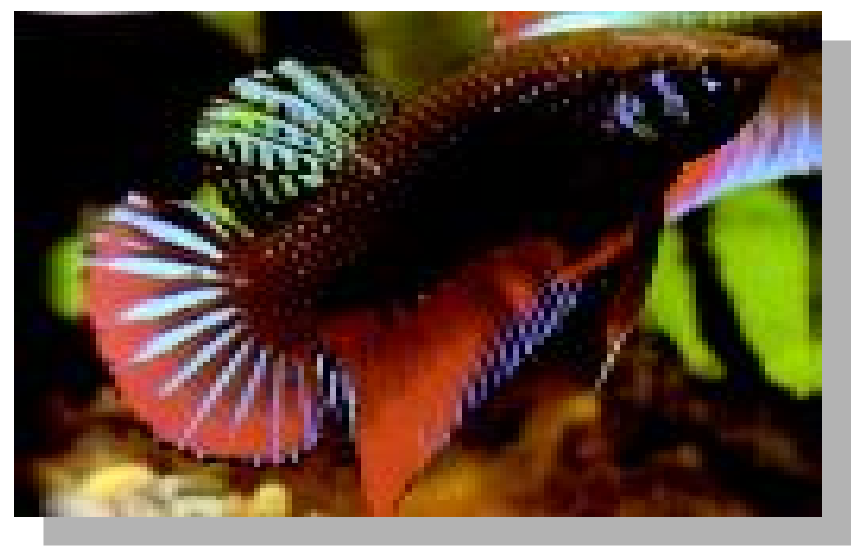

Cupang laga (Betta imbelis) 


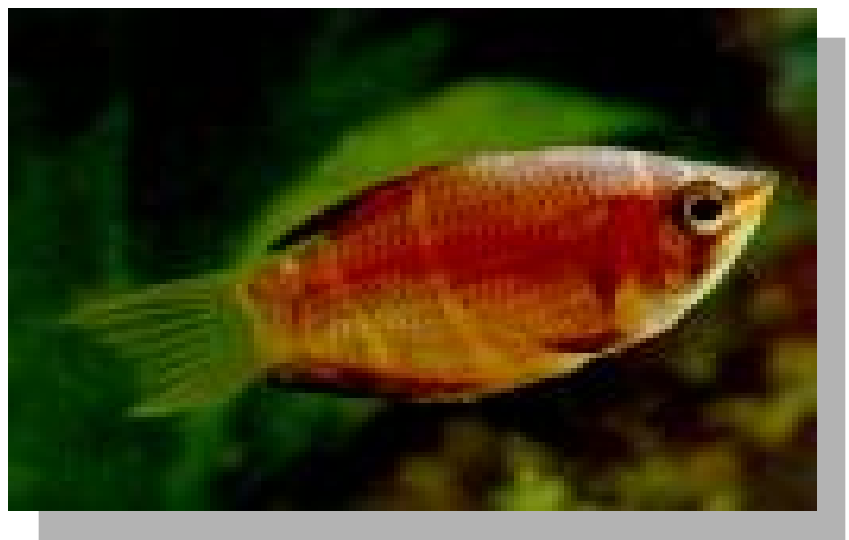

Sepat batik (Sphaerychthys osphronemoides)

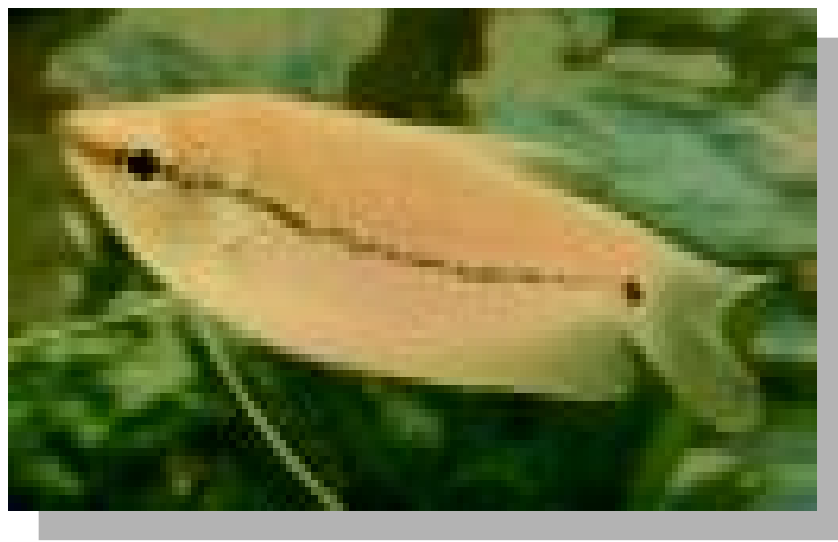

Sepat mutiara (Trichogaster leeri)

ranga yang sangat terkenal karena sering digunakan dalam eksperimen pewarnaan (karena ikan ini transparan) merupakan ikan yang cukup laku, dan belum ada yang membudidayakannya.

Familia Cobitidae, merupakan familia dimana jenis Botia sebagai primadona ikan hias air tawar berada. Ikan ini diambil dari alam sangat intensif. Dari beberapa informasi paling kurang setiap eksportir menampung

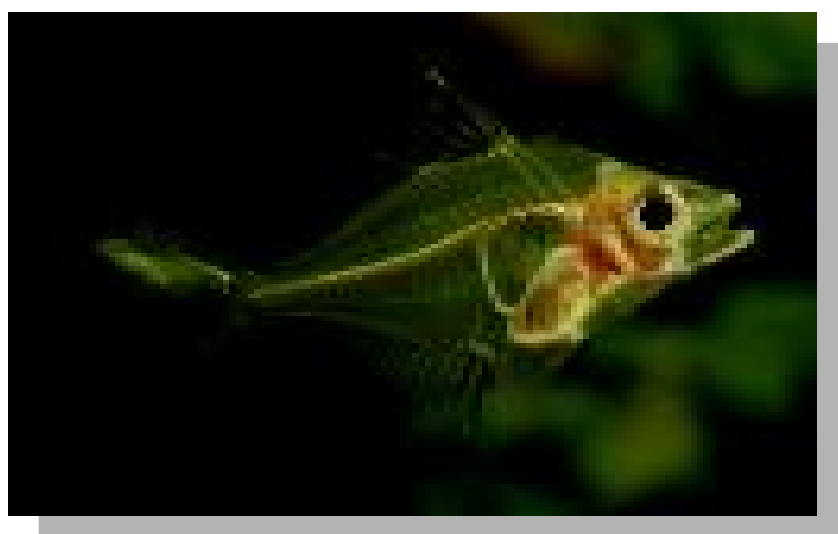

Glassfish (Chanda ranga)

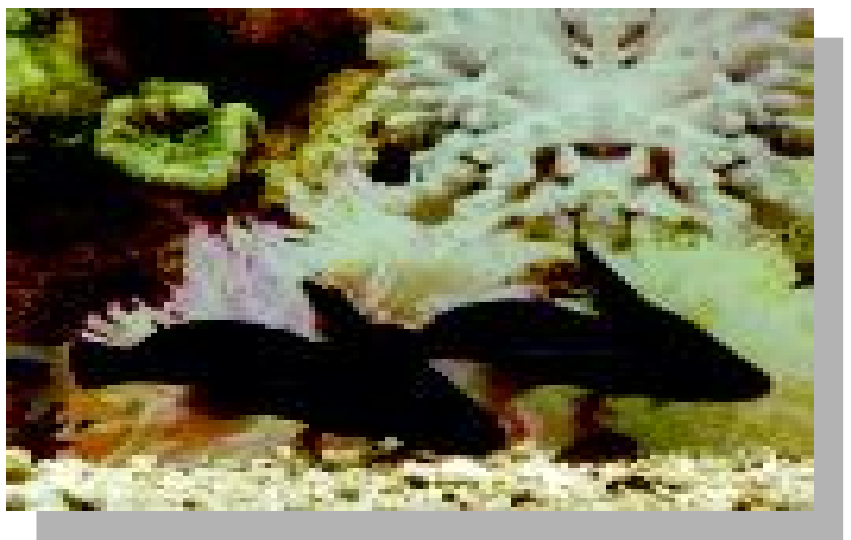

Black lancer catfish (Bagrychthys hypselopterus)

ikan ini satu juta ekor pertahun dan terjual habis. Didaerah Jabodetabek tidak kurang dari 50 eksportir, belum lagi ikan yang keluar dari daerah asal langsung ke Singapura. Dapat dibayangkan jumlah yang dikuras dari alam setiap tahunnya. Walaupun ikan botia saat ini telah dapat dibudidayakan, namun masih terbatas di instansi penelitian. Belum ada peternak ataupun pengusaha perikanan yang berminat serius untuk mencobanya.

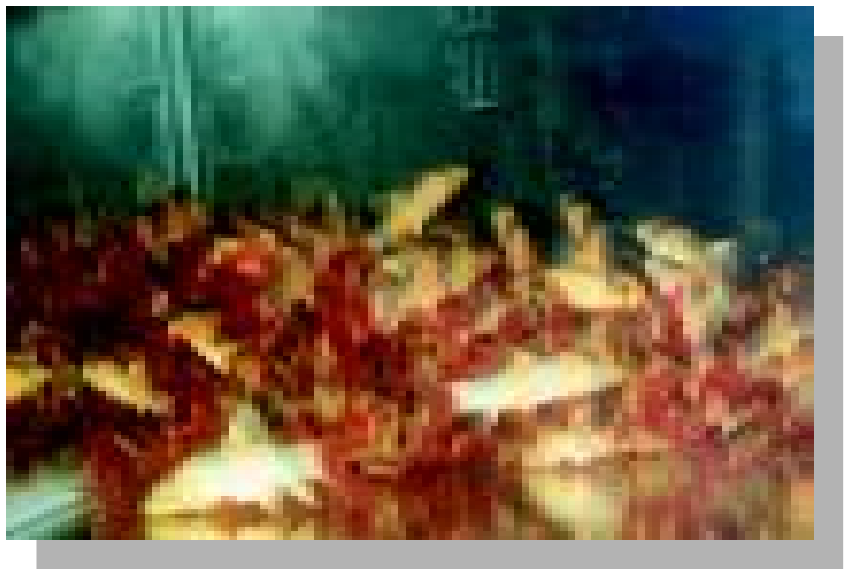

Botia (Botia macracantha)

Familia Cyprinidae didominasi oleh jenis Puntius dan Rasbora. Spesies ikan ini sangat banyak dan di daftar para eksportir juga selalu ada. Dua tahun yang lalu (2006-2007) masih mudah untuk mendatangkan ikan-ikan ini dari Sumatera dan Kalimantan. Namun saat ini (2009) menurut para eksportir sudah mulai susah untuk mendapatkannya.

Jenis lain yang sangat populer adalah ikan kelompok Rainbow atau dari familia Melanotaenia. Sangat diburu oleh para hobiis. Karena asalnya dari Papua dan habitatnya yang susah dijangkau sehingga ikan ini secara teori masih aman dari kepunahan. 


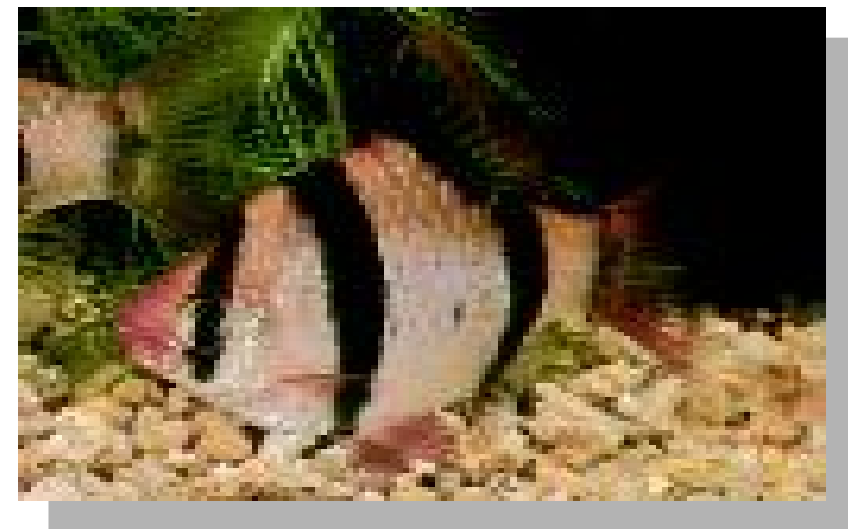

Barb (Puntius tetrazona)

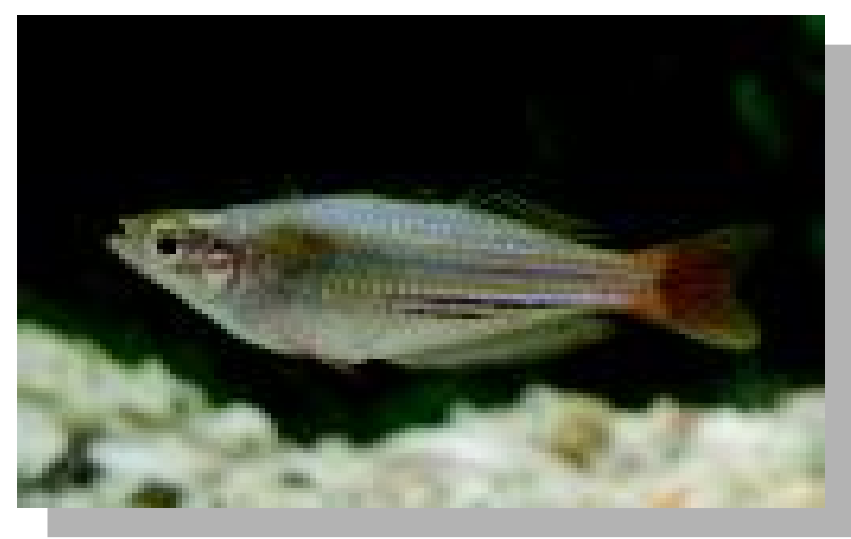

Maculochi rainbow (M. Maculochi)

Bintang ikan hias air tawar yang tak dapat diabaikan adalah dari Familia Osteoglosidae yaitu Arwana. Nilainya yang sangat mahal terutama yang Super Red tentu merupakan kekayaan yang harus dipelihara. Sudah banyak dibudidayakan, namun demikian keberadaannya di alam sebagai plasma nutfah dan sumber asli genetika amat perlu dilestarikan.

Jenis lain yaitu Siluridae, Tetraodontidae dan Toxotidae juga merupakan ikan yang cukup diminati. Ikan Datniodes

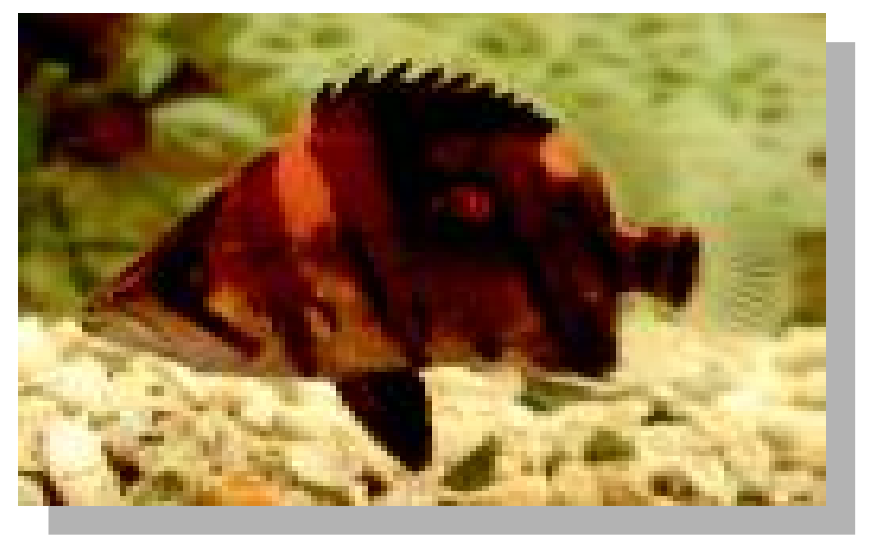

Tiger fish (Datniodes microlepis)

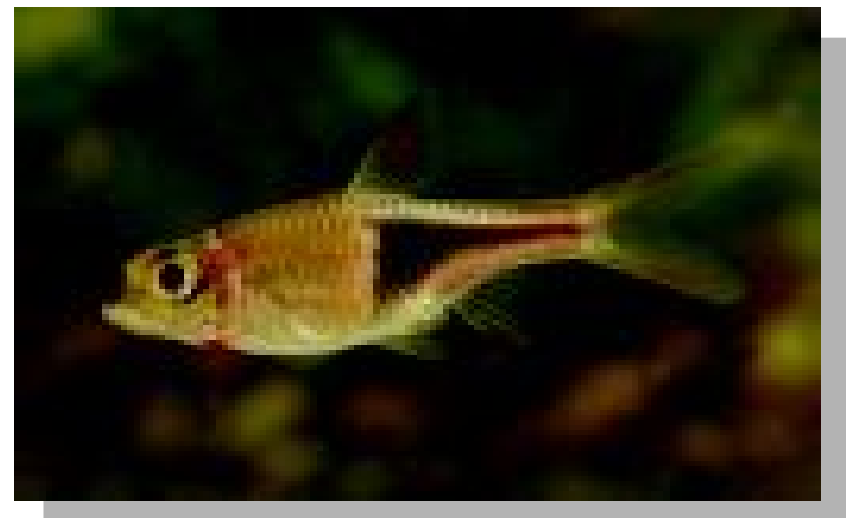

Harlequin (Rasbora heteromorpha)

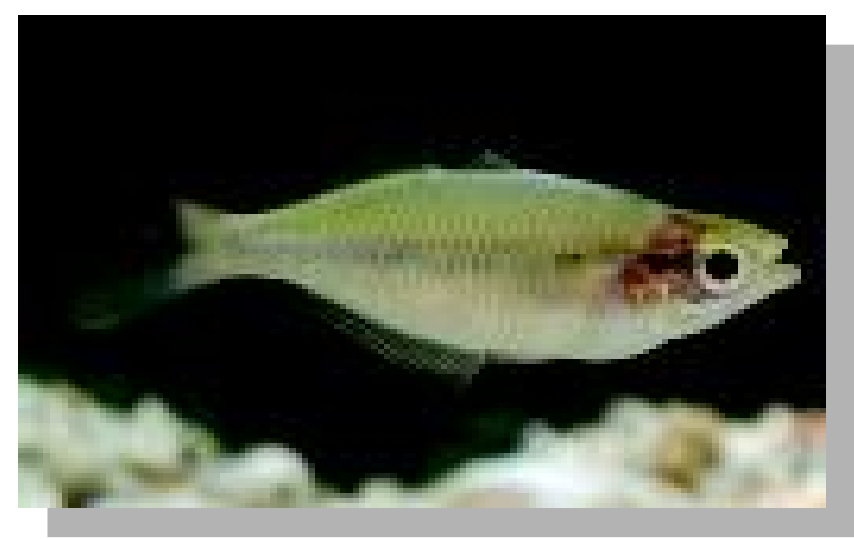

Yellow rainbow (M. herbertaxelrodi)

atau jenis Tiger Fish saat ini cukup banyak dicari dengan tren untuk dipelihara bersama ikan pari (Portamotrygon sp.)

Dari harga ikan yang kecil-kecil seperti Rasbora yang hanya sekitar Rp. 600,-/ekor sampai Arwana yang bisa mencapai Rp. 10 juta/ekor merupakan kekayaan alam yang tiada taranya. Walaupun nilai per ekornya kecil tetapi jumlahnya sangat banyak. Yang tercatat mungkin hanya beberapa juta ekor/tahunnya tetapi tentu dalam kenyataannya lebih dari jumlah tersebut.

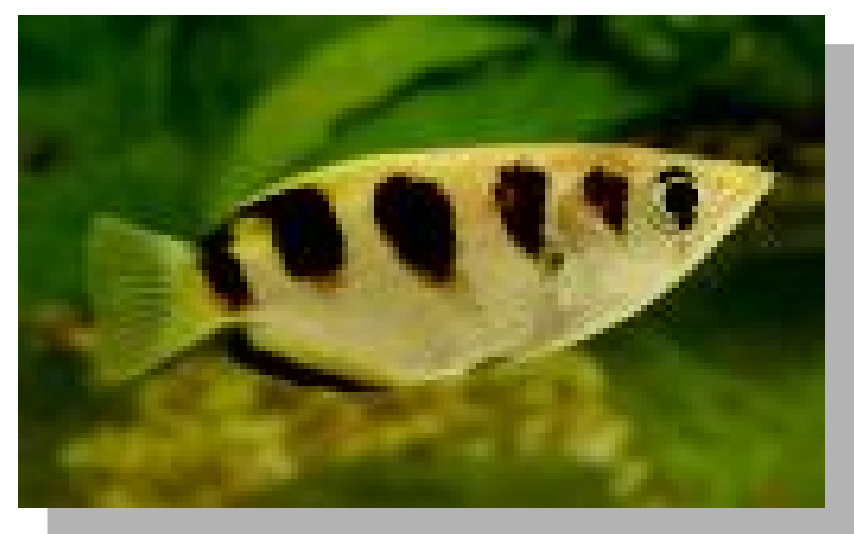

Ikan sumpit (Toxotes jaculatrix) 
Tabel 1. Jenis ikan alam dan introduksi yang diekspor dari Indonesia

\begin{tabular}{lcccc}
\hline Jenis ikan & Jumlah & $\begin{array}{c}\text { Sudah } \\
\text { budi daya }\end{array}$ & $\begin{array}{c}\text { Belum } \\
\text { budi daya }\end{array}$ & $\begin{array}{c}\text { Sudah/dalam } \\
\text { penelitian }\end{array}$ \\
\hline Alam & 141 & 44 & 97 & 30 \\
Introduksi & 183 & 155 & 29 & - \\
Jumlah & $\mathbf{3 2 4}$ & $\mathbf{1 9 8}$ & $\mathbf{1 3 6}$ & $\mathbf{3 0}$ \\
Non ikan & 12 & 8 & 4 & 3 \\
\hline
\end{tabular}

Penurunan produksi di alam yang terus terjadi tentu sangat disayangkan, karena akan menurunkan pula devisa dan Sumber Daya Ikan Hias ini. Belum lagi spesies non ikan yang saat ini mulai banyak pula diperjual belikan seperti Cherax sp. dan udang kecil (Caridina sp.) yang jumlahnya sekitar 8 spesies.

Kerusakan alam akibat polusi, perusakan hutan yang mengancam penurunan jumlah dan kualitas air, maupun penangkapan yang berlebih merupakan andil yang tak dapat dipungkiri akan menghabiskan semua sumber daya perairan tawar. Dibalik itu adanya banjir yang terus menerus terjadi juga menurunkan produksi karena nelayan atau pengumpul tidak mendapatkan ikan tangkapan.

\section{IKAN INTRODUKSI}

Tercatat ada sekitar 183 jenis ikan introduksi yang sudah masuk ke Indonesia (Tabel 1 dan Tabel Lampiran 2.). Sekian banyak ikan introduksi justru sudah banyak yang dibudidayakan di Indonesia. Iklim Indonesia yang tropik cocok untuk ikan-ikan ini karena kebanyakan datang dari daerah tropik pula. Daerah budidaya yang paling besar adalah daerah Jabodetabek, karena disini pula perdagangan, para eksportir dan importir ikan hias berada. Umumnya para importir dan eksportir yang tahu dan mengerti kebutuhan serta pasar ikan hias dunia dengan tren yang baru akan mendatangkan ikanikan dari negeri asalnya dan memberikannya pada peternak untuk ditangkarkan. Produksinya akan kembali kepada para eksportir yang akan mengekspornya ke seluruh penjuru negeri yang membutuhkan. Jenis yang belum dibudidayakan adalah merupakan ikan yang diimpor dan direekspor kenegara lainnya.

Jenis paling banyak adalah dari Familia Characidae, Cichlidae, Cyprinidae dan jenis ikan Catfish. Jenis lain yang juga cukup banyak dikembang biakkan adalah Familia Poecilidae dan sedikit dari familia Anabantidae serta Notopteriidae.

Familia Characidae yang banyak merupakan ikan-ikan kecil dari jenis tetra. Berpuluh jenis tetra sudah berhasil dikembang biakkan oleh para peternak di daerah Jabodetabek, terutama daerah Selatan seperti Depok dan Bogor. Namun sesuai dengan hukum pasar ikan yang dulunya mahal dengan banyaknya peternak yang berhasil memproduksi jenis tetra ini maka harga yang menukik jatuh membuat saat ini beberapa jenis tetra mulai ditinggalkan, misal black tetra, blue eyes dan neon tetra.

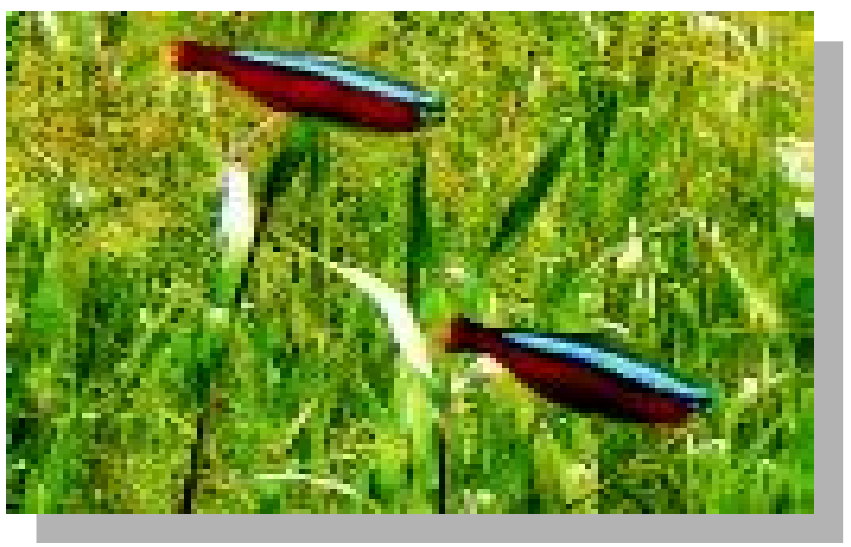

Cardinal tetra (Paracheirodon axelrodi)

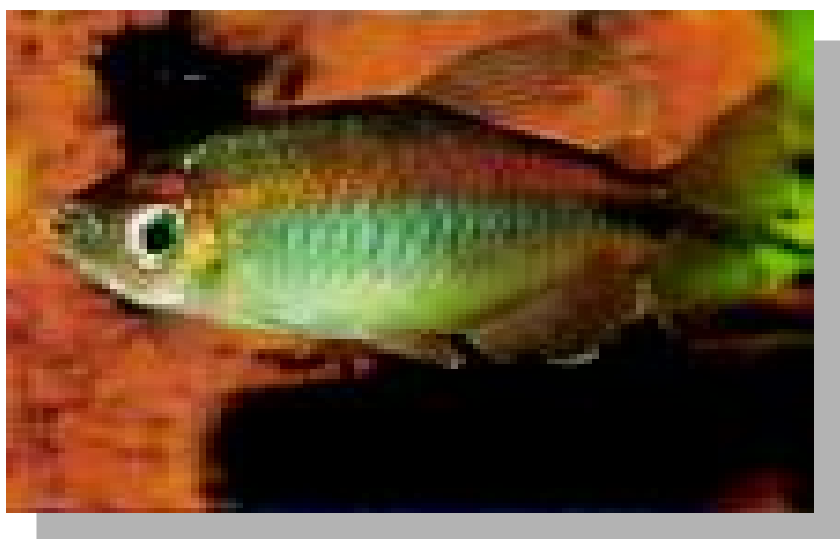

Congo tetra (Phenacogrammus interuptus)

Familia Cichlidae merupakan jenis yang amat banyak dibudidayakan di Indonesia. Jenis yang berukuran sedang seperti diskus dan maanvis sudah berpuluh tahun para peternak membudidayakannya. Peternak ikan jenis ini tersebar ke seluruh Jabodetabek. Malahan ikan diskus sudah banyak para hobiis mengadakan kontes dengan berbagai varitas dari hasil hibridisasi yang mereka kerjakan. Sampai saat inipun diskus yang dijuluki "The King of Aquarium" ini masih tetap digemari dan banyak peternak yang mengembang biakkannya. Siklid lain yang sangat digemari adalah ikan Lou Han yang sempat berjaya pada tahun 2000 an. Jenis lain mungkin tidak terlalu terkenal seperti jenis diatas namun demikian cukup banyak pula yang menternakkannya, seperti Oscar, Auratus, beberapa jenis dari genus Cichlasoma, Cyphlotilapia, dll. 


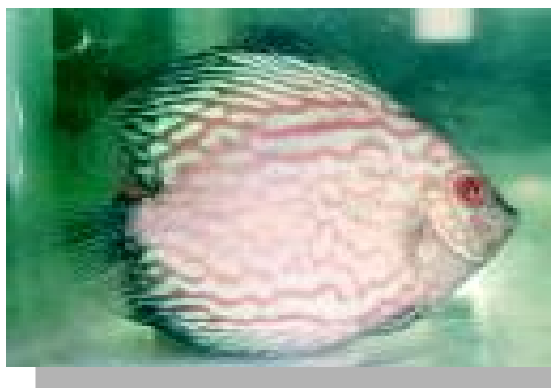

Diskus (Symphysodon discus)

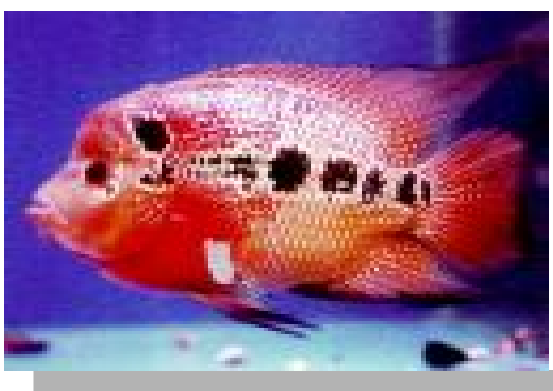

Lou han (Cichlasoma sp.)

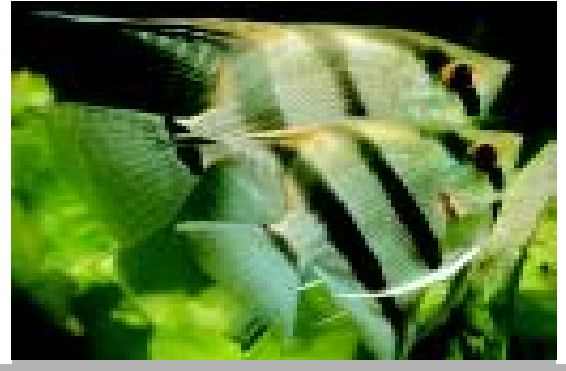

Maanvis (Pterophyllum scalare)

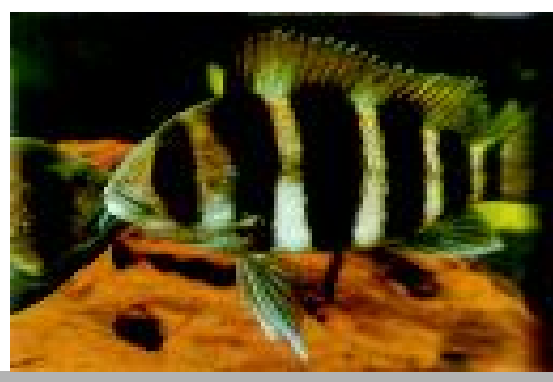

Frontosa (Cyphlotilapia frontosa)

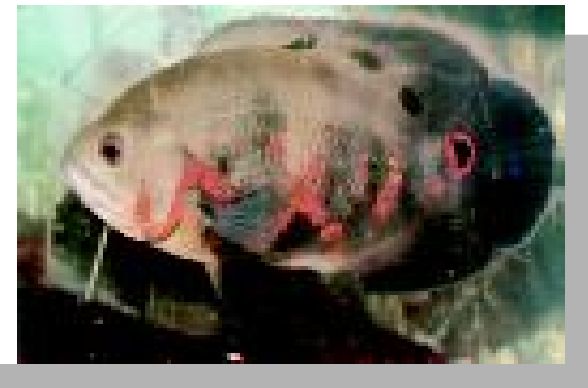

Oscar (Astronotus ocellatus)

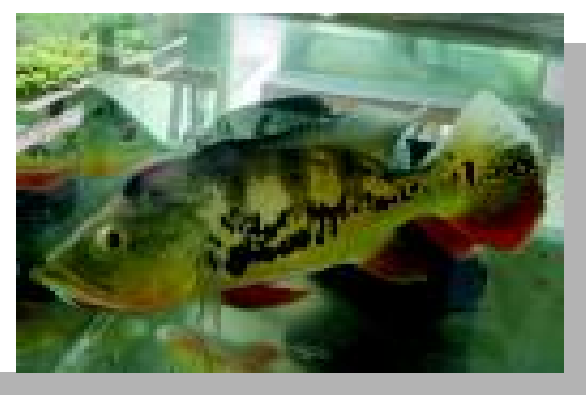

Cichla (Cichlasoma ocellaris)
Dari familia Cyprinidae tentu semua orang kenal ikan koi dan koki yang sudah puluhan tahun diternaktangkarkan disini. Varitas yang semakin bervariasi menandakan betapa ikan ini sangat disukai para konsumen dan penghobi di negeri ini. Ekspor ikan koki ke Singapura kebanyakan adalah ukuran kecil-kecil. Jenis Redfin shark juga sudah banyak dibudidayakan terutama yang albino.

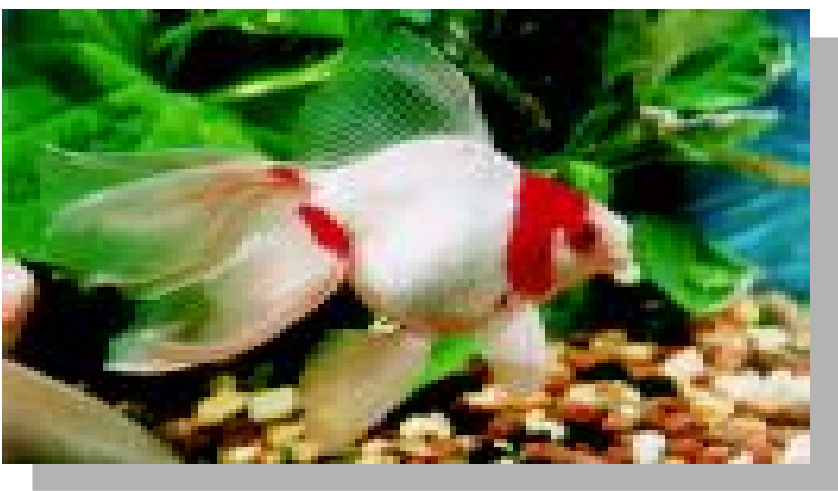

Mas koki (Carrasius auratus)

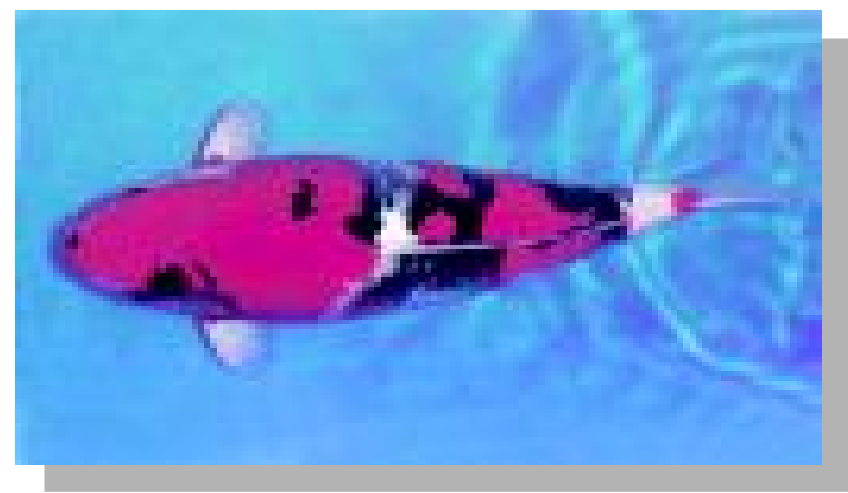

Koi (Cyprinus carpio)

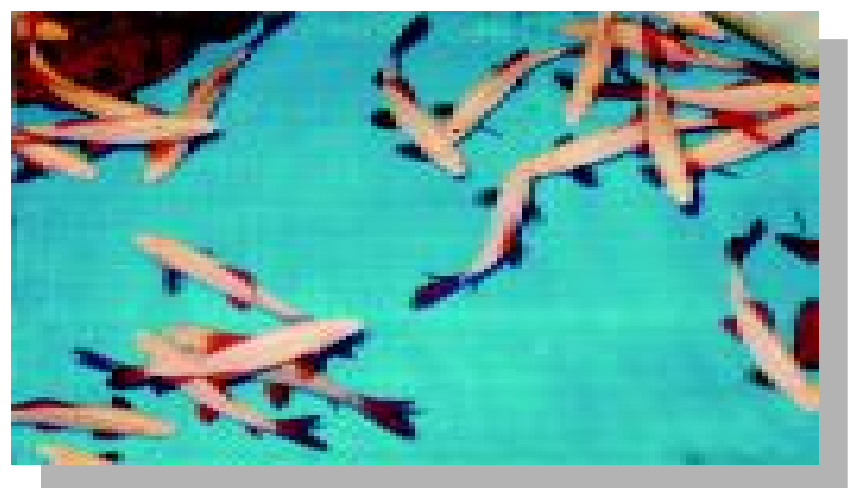

Redfin shark albino (Ephalzeorhynchus frenatus) 
Jenis Catfish seperti Red Tail Catfish, Tiger Catfish juga sudah banyak dipijahkan para peternak. Demikian pula catfish kecil berbagai macam Corydoras sudah lama para peternak mengembang biakkan ikan ini.

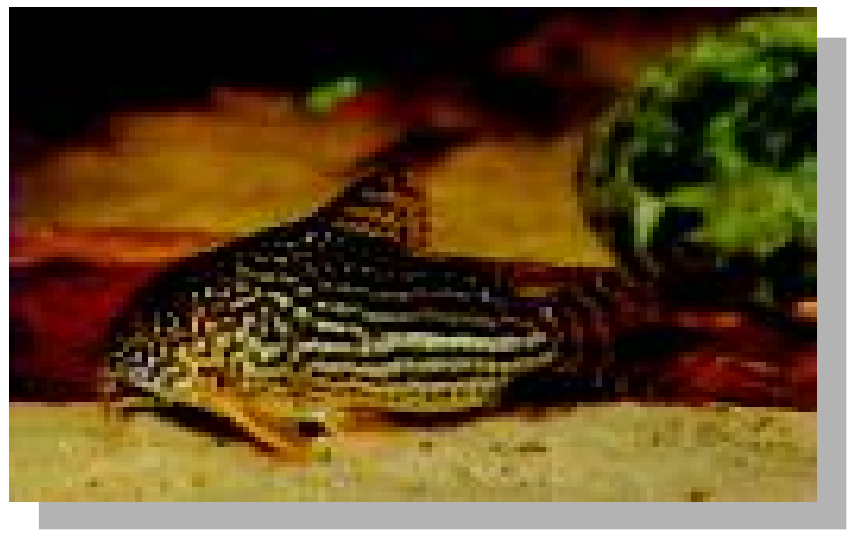

Corydoras sterbai

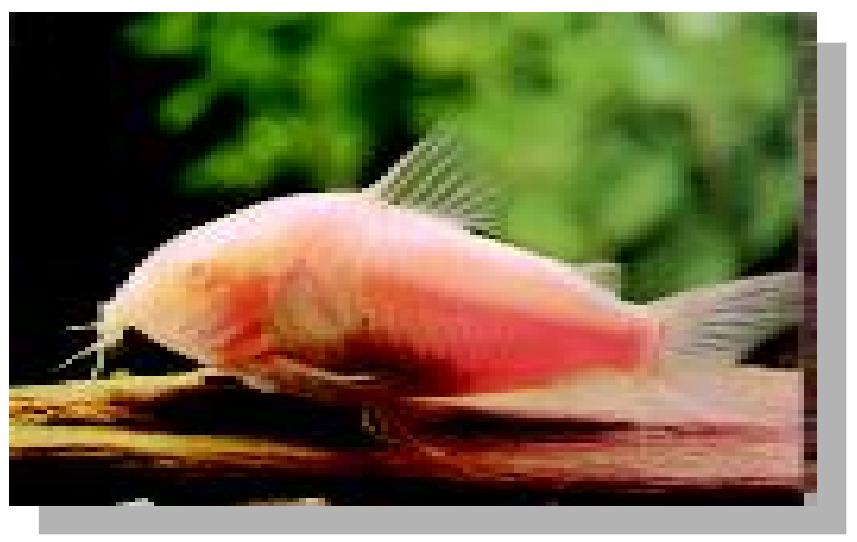

Corydoras aenes (albino)

Ikan pari dari familia Portamotrygon yang berasal dari Amerika Latin (Sungai Amazon) juga sudah dibudidayakan di Indonesia walaupun masih terbatas beberapa orang saja karena harganya yang amat mahal.

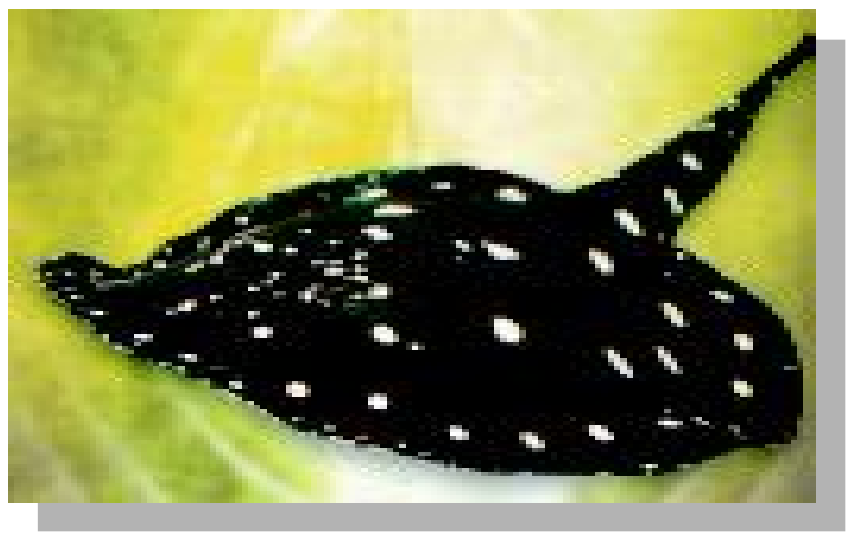

Pari tawar (Portamotrygon sp.)

\section{DOMESTIKASI DAN BUDIDAYA}

Domestikasi sebagai cara untuk mempertahankan plasma nutfah dapat dilakukan dalam suaka ataupun dalam tempat budidaya, farm-farm ataupun tempat-tempat penelitian. Dapat pula dilakukan di tempat-tempat wisata air seperti Taman Akuarium Air Tawar, juga tempat Agrowisata daerah.

Sementara budidaya merupakan salah satu cara alternatif yang dapat dilakukan untuk mempertahankan produksi. Walaupun sebenarnya tidak dapat atau mungkin tidak akan mampu berpacu dengan kerusakan atau pemusnahan setiap spesies mengingat banyaknya spesies yang ada di alam. Namun demikian masih merupakan satu-satunya cara yang paling bagus untuk diterapkan, selain dapat memenuhi kebutuhan secara berkesinambungan juga dapat tetap melestarikan sumber daya ikan. Biaya untuk memulai dengan penelitian tentu mahal, terutama untuk ikan yang langka, tetapi hasilnya akan jelas.

Tidak akan ada ikan yang terbuang percuma, karena ikan budidaya biasanya juga lebih dapat bertahan hidup daripada ikan yang liar. Banyak strain baru yang dapat dihasilkan dari budidaya dan ini akan didapatkan pula nilai tambah yang tidak sedikit. Hobiis ikan senantiasa menghendaki ikan jenis baru, dan para ahli genetika saat ini dapat bereksperimen untuk ikan hias ini.

Dibutuhkan riset yang lama dan terus menerus, SDM yang cukup dan tentu dana yang tidak sedikit. Apalagi bagi ikan murah seperti beberapa jenis rasbora yang sebenarnya memang tidak layak sebagai komoditas usaha; karena harganya yang murah sehingga para peternak malas untuk membudidayakannya. Kemungkinan hanya melalui restocking jenis ini bisa terselamatkan. Harus dilakukan pemilihan prioritas jenis dengan membuat list-nya.

Ironinya jenis ikan hias introduksi yang dibudidayakan lebih banyak dari yang alami atau asli. Walaupun mudah dimengerti karena tentunya perhitungan secara ekonomi ikan-ikan yang didatangkan atau introduksi lebih mempunyai nilai ekonomi daripada ikan alam. Apalagi sudah barang tentu para importir tak akan memilih ikan yang tidak bernilai.

Hal inilah yang membuat jenis ikan hias alam banyak yang akhirnya punah atau hilang dari peredaran. Sebagai contoh ikan Black Shark atau irengan yang dulu di Jawa dan Sumatera amat banyak, sekarang sudah tak ada sama sekali, ikan Balashark dari Sungai Batang Hari saat ini juga sudah tidak ada, Balashark yang beredar di pasaran adalah dari Thailand. 


\section{PENUTUP}

Perdagangan ikan hias air tawar yang sudah mendunia akan terus meningkat seiring dengan meningkatnya jumlah penduduk dan kesadaran akan lingkungan terutama "pet animal" yang ramah dan tak mengganggu. Dampak peningkatan ini tentunya adalah adanya kenaikan devisa dari ekspor, namun pengurasan plasma nutfah ikan yang juga terus meningkat memberikan kekhawatiran akan habisnya sumber daya ikan. Dengan demikian diperlukan langkah antisipasi agar semua plasma nutfah tetap lestari sementara deviasa juga dapat meningkat. Budidaya, konservasi serta adanya peraturan yang mengarah pada perlindungan sumber daya ikan mungkin mendesak untuk dilaksanakan dengan cepat.

\section{DAFTAR ACUAN}

NAFED (National Agency For Export Development). 2006. Directory Indonesian Ornamental Fish Exporters. Ministry of Industry and Trade, Republic of Indonesia. Jakarta, 5 pp.

Putro, S. A. Poernomo, S. Muhdi, E. Setiabudi, Isjaturradhiah, D. Hertanto, \& U.N. Dahlia. 2004. Direktori ikan hias, Penebar Swadaya, Jakarta, p. 3-4.

Sakurai, A., Y. Sakamoto, \& F. M ori. 1990. Aquarium Fish of the World. The Comprehensive guide to 650 species. Chronicle Books. San Fransisco, 288 pp.

Satyani, D., A. Sudradjat, \& K. Sugama. 2007. Ikan hias air tawar Indonesia. Pusat Riset Perikanan Budidaya. Jakarta, $170 \mathrm{hlm}$. 
Lampiran 1. Ikan hias asli Indonesia ekspor yang belum dan sudah dibudidayakan

\begin{tabular}{|c|c|c|c|c|c|}
\hline \multirow{2}{*}{ Familia } & \multirow{2}{*}{ Genus } & \multicolumn{2}{|c|}{ Spesies } & \multicolumn{2}{|c|}{ Budidaya } \\
\hline & & Scientific name & Common name & Sudah & Belum \\
\hline \multirow[t]{26}{*}{ Anabantidae } & Betta & B. albimarginata & Albi Betta & + & + \\
\hline & & B anabatoides & Pearly Betta & & + \\
\hline & & B. anjunganensis & Anjungan Betta & & + \\
\hline & & B. coccina & Coccina Betta & + & \\
\hline & & B. canoides & Canoides Betta & + & \\
\hline & & B. fasciata & Fighting Fish & & + \\
\hline & & B. macrostoma & Brunei Beauty & + & \\
\hline & & B. paliplna & Palipina Betta & & + \\
\hline & & B. pugnac & Pugnax Betta & + & \\
\hline & & B. rutilan & Rutilan & & + \\
\hline & & B. splenden & Fighting Fish & + & \\
\hline & & B. strohi & Strohi & & + \\
\hline & & B. taeniata & Taeniata Fighting Fish & + & \\
\hline & & B. rubra & Red Betta & + & \\
\hline & & B. unimaculata & Unimaculata & & + \\
\hline & Helostoma & H. temmincki & Kissing Gouramy & + & \\
\hline & Macropodus & M. opercularis & Paradise Fish & + & \\
\hline & Osphronemus & 0. gouramy & Giant Gouramy & + & \\
\hline & Polycanthus/Belontia & P. haselti & Java Combtail & & + \\
\hline & Sphaerichthys & S. osphromenoides & Chocolate Gouramy & + & + \\
\hline & & S. selatanensis & $\begin{array}{l}\text { Thin-barred Chocolate } \\
\text { Gouramy }\end{array}$ & + & \\
\hline & & S. vailantei & Vailanti/Green Gouramy & & + \\
\hline & Trichogaster & T. leeri & Pearl Gouramy & + & \\
\hline & & T. pectoralis & Snakeskin Gouramy & $+1-$ & \\
\hline & & T. trichopterus & Blue Gouramy & + & \\
\hline & Trichopsis & T. vittatus & Croaking Gouramy & + & \\
\hline Ariidae & Arius & Arius sp. & Orange Fin Catfish & & + \\
\hline \multirow[t]{6}{*}{ Bagridae } & Bagrichthys & B. hypselopterus & Black Lancer Catfish & & + \\
\hline & Bagroides & B. melapterus & Harlequin Lancer Catfish & & + \\
\hline & Chaka & C. bankanensis & Frogmouth Fish & & + \\
\hline & Mystus & M. bimaculatus & Bar-tail Mystus & & + \\
\hline & & M. microcanthus & Two Spot Catfish & & + \\
\hline & Leiocasis & L. siamensis & Barred Siammese catfish & & \\
\hline Balitoridae & Gastromyzon & G. borneensis & Borneo Sucker & & + \\
\hline Chandidae & Chanda & C. (parambasis) ranga & Glassfish & & + \\
\hline \multirow[t]{4}{*}{ Channidae } & Channa & C. lucius & Lucius Snake Head & & + \\
\hline & & C. micropeltes & Red Snake Head & & + \\
\hline & & C. pleuropthalmus & Pleurophthalmus Snake & & + \\
\hline & & C. striata & Chevron Snake Head & & + \\
\hline Clariidae & Clarias & C. batrachus & Walking Catfish & + & \\
\hline \multirow[t]{5}{*}{ Cobitidae } & $\begin{array}{l}\text { Acanthopthalmus/ } \\
\text { Pangio }\end{array}$ & A./P. anguilaris & Eel Loach & + & \\
\hline & & A. kuhli & Kuhli Loach & & + \\
\hline & & A. semicinctus & Half - Banded Loach & & + \\
\hline & & A. javanicus & Javanese Loach & & + \\
\hline & & A. myersi & Black Kuhlii & & + \\
\hline
\end{tabular}


Lanjutan Lampiran 1

\begin{tabular}{|c|c|c|c|c|c|}
\hline \multirow{2}{*}{ Familia } & \multirow{2}{*}{ Genus } & \multicolumn{2}{|c|}{ Spesies } & \multicolumn{2}{|c|}{ Budidaya } \\
\hline & & Scientific name & Common name & Sudah & Belum \\
\hline & \multirow[t]{2}{*}{ Botia } & B. hymenophysa & Green Botia & & + \\
\hline & & $\begin{array}{l}\text { B. macracantha/ } \\
\text { Chromobotia macracantha }\end{array}$ & Tiger Botia/Clown Loach & $+*$ & \\
\hline \multirow[t]{46}{*}{ Cyprinidae } & Badis & Badis badis & Badis Badis & + & \\
\hline & Balanteocheilus & B. melanopterus & Bala Shark & + & \\
\hline & Barbichthys & B. laevis & Sucker Barb & & + \\
\hline & Capoeta & C. oligolepis & Checkerboard Barb & + & \\
\hline & & C. semifasciolatus & Half Banded Barb & & + \\
\hline & Chela & C. laubuca & Indian Hatchetfish & & + \\
\hline & Chela/Paracheila & C/P. oxygastroides & & & + \\
\hline & Crossocheilus & $\begin{array}{l}\text { C. gnathopogon/ } \\
\text { siamensis }\end{array}$ & Flying Fox (White) & & + \\
\hline & & C. oblongus & Short-nosed Flying Fox & & + \\
\hline & Cyclocheilichthys & C. enoplos (c. apogon) & & & + \\
\hline & Dangila & D. cuvieri & & & + \\
\hline & & D. ocellata & & & + \\
\hline & Ephalzeorhynchus & E. frenatus & Red-fined Shark & & + \\
\hline & & E. kalopterus & Flying Fox (Red) & & + \\
\hline & Hampala & H. ampalong & Hampala & & + \\
\hline & & H. microlepidota & Silver and Red Barb & & + \\
\hline & Labeo & L. variegates & Variegated Shark & & + \\
\hline & Leptobarbus & L. hoeveni & Red-finned Cigar Shark & $+^{*}$ & \\
\hline & Luciosoma & L. sitigerum & Long-finned Apollo Sahrak & & + \\
\hline & M orulius/Labeo & M. chrysophekadion & Black Shark & & + \\
\hline & Oryzias & 0. javanicus & Javanese Rice Fish & & + \\
\hline & Osteocheilus & 0. bornensis & & & + \\
\hline & & 0. haselti & Hard-lipped barb & & + \\
\hline & & 0. vittatus (macrolepidota) & Black Banded Osteochilus & & + \\
\hline & Puntius/Barbus & P. aurulius & Aurilius Barb & & + \\
\hline & & P. conchonius & Rossy Barb & & + \\
\hline & & P. fasciatus & Panda Barb & & + \\
\hline & & P. filamentosus & Black Spot Barb & & + \\
\hline & & P. hexagona & Six Banded Barb & & + \\
\hline & & P. johorensis & Johorensis Barb & & \\
\hline & & P. lineatus & Stripped Barb & & + \\
\hline & & P. nigrofasciatus & Black Rubby Barb & + & \\
\hline & & P. oligolepis & Checker Barb & & + \\
\hline & & P. pentazona & Banded Pentazona Barb & + & \\
\hline & & P. rhomboocellatus & Rhombo Barb & & + \\
\hline & & P. sachsi & Golden Barb & + & \\
\hline & & P. schwanefeldi & Tinfoil Barb & + & \\
\hline & & P. semifasciolatus & & & + \\
\hline & & P. tawarensis & Tawarensis Barb & + & + \\
\hline & & P. tetrazona & Tiger Barb & + & \\
\hline & & P. tetrazona rummynose & Rummynose Barb & + & \\
\hline & & P. titteya & Cherry Barb & & + \\
\hline & & P. wandersii & Wandersii barb & & + \\
\hline & Rasbora & R. agilis & Blackstripped rasbora & & + \\
\hline & & R. argyrotaenia & Black-edged Rasbora & & + \\
\hline & & R. axelrodi & Glow Light rasbora & & + \\
\hline
\end{tabular}


Lanjutan Lampiran 1

\begin{tabular}{|c|c|c|c|c|c|}
\hline \multirow{2}{*}{ Familia } & \multirow{2}{*}{ Genus } & \multicolumn{2}{|c|}{ Spesies } & \multicolumn{2}{|c|}{ Budidaya } \\
\hline & & Scientific name & \multirow{2}{*}{$\begin{array}{l}\text { Common name } \\
\text { Bangka rasbora }\end{array}$} & \multirow[t]{2}{*}{ Sudah } & \multirow{2}{*}{$\frac{\text { Belum }}{+}$} \\
\hline & & R. bankanensis & & & \\
\hline & & R. brigittae & Mosquito Rasbora & & + \\
\hline & & R. brittani & Brittan's Rasbora & & + \\
\hline & & R. caudimaculata & Spot-tailed Rasbora & & + \\
\hline & & R. dorsiocellata macroptalma & Hi-spot Rasbora & & + \\
\hline & & R. dusonensis & Rosefin Rasbora & & + \\
\hline & & R. elegans & Elegan's Rasbora & & + \\
\hline & & R. einthoveni & Long-band Rasbora & & \\
\hline & & R. espei & Narrow-wedge Harlequin & & \\
\hline & & R. heteromorpha & Harlequin Rasbora & + & \\
\hline & & R. kalochroma & Big-spot Rasbora & & + \\
\hline & & R. maculate & Spotted Rasbora & & + \\
\hline & & R. pauciperforata & Red-line rasbora & & + \\
\hline & & R. paviei & Line Rasbora & & \\
\hline & & Rasbora sp. & Red Fin Rasbora & & \\
\hline & & R. sumatrana & Sumatran Rabora & & + \\
\hline & & R. taeniata & Teniata rasbora & & + \\
\hline & & R. trilineata & Scissortail Rasbora & + & \\
\hline & Sawbwa & S. resplenden & Naked Microrasbora & & \\
\hline & Thynnichthys & T. thyonides & Thynoid M innow & & + \\
\hline \multirow[t]{2}{*}{ Dasyatidae } & Dasyatis/Portamotrygon & D. sephen & Freshwater Stingray & $+1-$ & \\
\hline & & D. bleekeri & Borneo Stingray & & + \\
\hline \multirow[t]{4}{*}{ Gobiidae } & Brachygobius & B. nunus (doriae) & Bumble Bee Goby & & + \\
\hline & Glossogobius & G. giuris & Flat Head Goby & & + \\
\hline & & N. robusta & Butterfly Fish & & + \\
\hline & Stigmatogobius & S. sadanundio & Knight Goby & & + \\
\hline \multirow[t]{2}{*}{ Hemirhamphidae } & Dermogenys & D. pusilus & Green Pike Head & & + \\
\hline & & D. sumatranus & Malayan Halfbeak & & + \\
\hline \multirow[t]{4}{*}{ Mastecem belidae } & Mastacembelus & M. erythrotaenia & Fire Eel & & + \\
\hline & & M. maculata & Spiny Eel & & + \\
\hline & & M. unicolor & Spotted Eel & & + \\
\hline & Anguilla & A. bicolor & Eel & + & \\
\hline \multirow[t]{15}{*}{ Melanotaeniidae } & Glossolepis & G. incisus & Red Rainbow & + & \\
\hline & Iriatherina & I. werneri & Tradfin Rainbow & + & \\
\hline & Melanotaenia & M. australia & Neon Redfin rainbow & + & \\
\hline & & M. bosemani & Boesemani Rainbow & + & \\
\hline & & M. herbert axelrodi & Yellow Rainbow & + & \\
\hline & & M. irianjaya & New Guinea Rainbow & & + \\
\hline & & M. lacustris & Kutubu/Blue Rainbow & & + \\
\hline & & M. macullochi & Mc'Culloch's Rainbow & + & \\
\hline & & M. multisquamata & Sepik Rainbow & & \\
\hline & & M. nigrans & Dark Australian Rainbow & + & \\
\hline & & M. papuae & Papuan Rainbow & + & \\
\hline & & M. parkinsoni & Parkinson's Rainbow & + & \\
\hline & & M. praecox & Neon Dwarf Rainbow & + & \\
\hline & & M. splendida inornata & Pigeon Blood Rainbow & + & \\
\hline & & M. trifasciata & Banded Rainbow & & + \\
\hline
\end{tabular}


Lanjutan Lampiran 1

\begin{tabular}{|c|c|c|c|c|c|}
\hline \multirow{2}{*}{ Familia } & \multirow{2}{*}{ Genus } & \multicolumn{2}{|c|}{ Spesies } & \multicolumn{2}{|c|}{ Budidaya } \\
\hline & & Scientific name & Common name & Sudah & Belum \\
\hline & $\begin{array}{l}\text { Telmatherinal } \\
\text { Marosatherina }\end{array}$ & T. ladigesi & Celebes Rainbow & + & \\
\hline M onodactylidae & M onodactylus & M. argenteus & Silver Mono & & + \\
\hline Nandidae & Nandus & N. nandus (nebulosus) & Leaf Fish & & + \\
\hline Notopteriidae & Notopterus & N. lopis (notopterus) & Knife Fish & + & \\
\hline Osteoglossidae & Scleropages & $\begin{array}{l}\text { S. formosus } \\
\text { S. jardini } \\
\text { S. legendrei }\end{array}$ & $\begin{array}{l}\text { Green/Silver Arowana } \\
\text { Papuan/Jardini Arowana } \\
\text { Red/Super Red Arowana }\end{array}$ & $\begin{array}{l}+ \\
+ \\
+\end{array}$ & \\
\hline Pangasidae & Pangasius & P. hypophthalmus/sutchi & Simmese Shark & + & \\
\hline Poecilidae & Poecilia & P. reticulata & Guppy & + & \\
\hline Scatophagidae & $\begin{array}{l}\text { Scatophagus } \\
\text { Selenotoca }\end{array}$ & $\begin{array}{l}\text { S. argus } \\
\text { S. multifasciata }\end{array}$ & $\begin{array}{l}\text { Red Scat } \\
\text { Silver Scat }\end{array}$ & & $\begin{array}{l}+ \\
+\end{array}$ \\
\hline Siluridae & $\begin{array}{l}\text { Ephalzeorhynchus } \\
\text { Kryptopterus } \\
\text { Wallago/Ompok }\end{array}$ & $\begin{array}{l}\text { E. kalopterus } \\
\text { K. bicirrhis } \\
\text { K. kryptopterus } \\
\text { K. minor } \\
\text { K. hexapterus } \\
\text { K. lais } \\
\text { K. macrocephalus } \\
\text { K. scheilbeides } \\
\text { W. myostoma } \\
\text { O. bimaculatus }\end{array}$ & $\begin{array}{l}\text { Flying Fox } \\
\text { Glass Catfish } \\
\text { Borneon's Glass Fish } \\
\text { Glass Catfish } \\
\text { White Glassfish } \\
\text { Glass Catfissh } \\
\text { Poorman's Glass Catfish } \\
\text { Yellow Glass Catfish } \\
\text { Butter Catfish } \\
\text { Maly Glass Fish }\end{array}$ & & $\begin{array}{l}+ \\
+ \\
+ \\
+ \\
+ \\
+ \\
+ \\
+\end{array}$ \\
\hline Tetraodontidae & Tetraodon & $\begin{array}{l}\text { T. biocellatus (palembangensis) } \\
\text { T. leiurus }\end{array}$ & $\begin{array}{l}\text { Figure Eight Puffer } \\
\text { Twin Spot Puffer }\end{array}$ & + & + \\
\hline Toxotidae & $\begin{array}{l}\text { Toxotes } \\
\text { Datniodes/Coius }\end{array}$ & $\begin{array}{l}\text { T. jaculatrix } \\
\text { D. microlepis }\end{array}$ & $\begin{array}{l}\text { Archer Fish } \\
\text { Tiger Fish }\end{array}$ & & $\begin{array}{l}+ \\
+\end{array}$ \\
\hline SPESIES NON IK & & & & & \\
\hline Crustacea & Caridina & C. aridina sp. & Rainbow/Zebra Shrimp & + & \\
\hline Parastacidae & Cherax & $\begin{array}{l}\text { C. monticula } \\
\text { C. Iorenzi } \\
\text { C. zebra }\end{array}$ & Papua Crayfish & $\begin{array}{l}+ \\
+ \\
+\end{array}$ & \\
\hline Pohichtidae & Neritina & Neritina sp. & Zebra/Red Snail & & + \\
\hline
\end{tabular}


Lampiran 2. Ikan hias introduksi ekspor yang belum dan sudah dibudidayakan di Indonesia

\begin{tabular}{|c|c|c|c|c|c|}
\hline \multirow{2}{*}{ Familia } & \multirow{2}{*}{ Genus } & \multicolumn{2}{|c|}{ Spesies } & \multicolumn{2}{|c|}{ Budidaya } \\
\hline & & Scientific name & Common name & Sudah & Belum \\
\hline \multirow[t]{6}{*}{ Anabantidae } & Colisa & C. labiosa & Thick Lipped Gouramy & + & \\
\hline & & C. Ialia & Dwarf Gouramy & + & \\
\hline & Ctenopoma & C. acustirostre & Leopard Ctenopoma & + & \\
\hline & Macropodus & M. opercularis & Paradise Fish & + & \\
\hline & Parosphromenus & P. filamentosa & Spike tail Licorice Gouramy & + & \\
\hline & & P. deissneri & Licorice Gouramy & + & \\
\hline \multirow[t]{4}{*}{ Aplocheilidae } & Aphyosemion & A. gardneri & Steel-blue Killi & + & \\
\hline & Aplocheilus & A. annulatus & Clown Killi & + & \\
\hline & & A. omalonotus & Golden pancax & + & \\
\hline & & A. panchax panchax & Yellow Panchax & + & \\
\hline \multirow[t]{2}{*}{ Ariidae } & Arius & Arius sp. & Orange-fin Salmon Catfish & & + \\
\hline & Ancistrus & A. dolichopterus & Big-fin Bristlenose & & + \\
\hline \multirow[t]{37}{*}{ Characidae } & Alestes & A. longipinis & Long Fin Characin & & \\
\hline & Aphyocarax & A. alburnus & False Flame Tetra & + & \\
\hline & & A. paraguayensis & White Spot Tetra & + & \\
\hline & & A. rathbuni & Red Belly Bloodfin & + & \\
\hline & Aplocheilichthys & A. normani & Norman's Lampeye & + & \\
\hline & & A. pumilus & Lake Lampeye & + & \\
\hline & Astyanax & A. mexicanus & Blind Cave Tetra & + & \\
\hline & & Astyanax sp. & Big-scale Astyanax & + & \\
\hline & Boehlkea & B. fredcochui & Blue King Tetra & + & \\
\hline & Brycinus & B. longipinnis & Long-Finned African Tetra & + & \\
\hline & Characeus & C. erythrurus & Yellow Finned Chalceus & + & \\
\hline & Chilodus & C. punctatus & Spotted Headstander & + & \\
\hline & Corynopoma & C. riisei & Swordtail Characin & + & \\
\hline & Gymnocorymbus & G. ternetzi & Black Tetra & + & \\
\hline & Hasemania & H. nana & Silver Tipped Tetra & + & \\
\hline & Hemigramopetersius & H. caudalis & Yellow Tail Congo Tetra & + & \\
\hline & Hemigrammus & H. bleheri & Rummynose Tetra & + & \\
\hline & & H. caudovittatus & Buenos Aires Tetra & + & \\
\hline & & H. erythrozonus & Glowlight Tetra & + & \\
\hline & & H. greimi & Flame Tetra & + & \\
\hline & & H. ocellifer & Head and Tail Light Tetra & + & \\
\hline & & H. pulcher & Garnet Tetra & + & \\
\hline & & H. rodwayi & Gold Tetra & + & \\
\hline & Hyphessobrycon & H. amandae & Ember Tetra & + & \\
\hline & & H. bentosi & Rosy Tetra & + & \\
\hline & & H. bi fasciatus & Yellow Tetra & + & \\
\hline & & H. callistus & Callistus Tetra & + & \\
\hline & & H. colombianus & Columbia Tetra & + & \\
\hline & & H. herbert axelrodi & Black Neon Tetra & + & \\
\hline & & H. innesi & Neon Tetra & + & \\
\hline & & H. loweae & Kitty Tetra & + & \\
\hline & & H. pulchripinnis & Kitti Tetra & + & \\
\hline & & H. rhodostomus & Rednose Tetra & & \\
\hline & & H. serpae & Serpae Tetra & + & \\
\hline & Inpachthys & I. kerri & Blue Emperor Tetra & + & \\
\hline & M egalompodus & M. megalopterus & Black Phantom Tetra & + & \\
\hline & & M. roseus & Redtail Phantom & + & \\
\hline
\end{tabular}


Lanjutan Lampiran 2

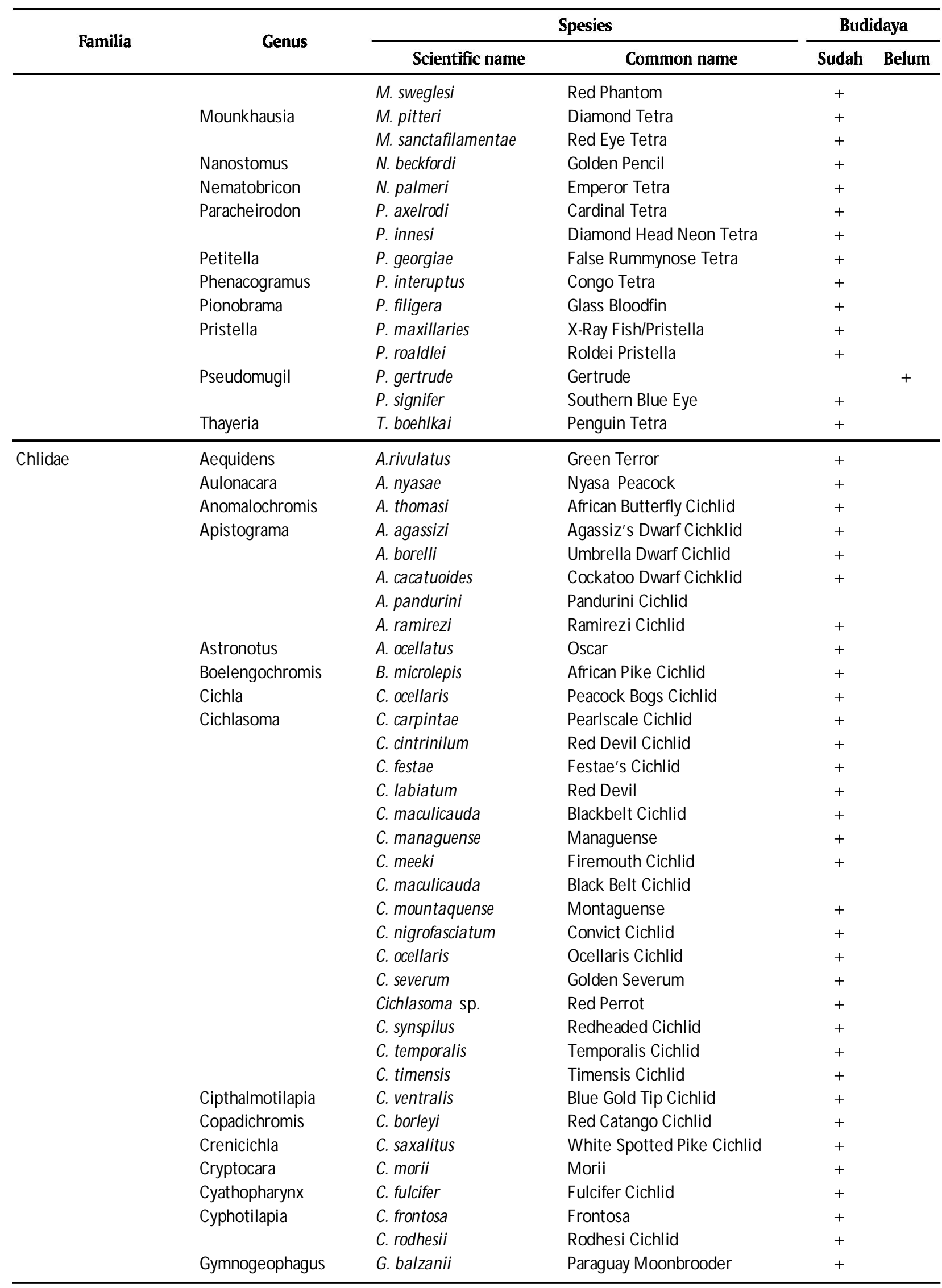


Lanjutan Lampiran 2

\begin{tabular}{|c|c|c|c|c|c|}
\hline \multirow{2}{*}{ Familia } & \multirow{2}{*}{ Genus } & \multicolumn{2}{|r|}{ Spesies } & \multicolumn{2}{|c|}{ Budidaya } \\
\hline & & Scientific name & Common name & Sudah & Belum \\
\hline & & G. steindachneri & Hondae Humphead Cichlid & & \\
\hline & Haplochromis & H. ahli & Electric Blue Cichlid & + & \\
\hline & & H. compressiceps & Malawi Eye Biter & & \\
\hline & & H. fuscotaeniatus & Fuscotaeniarus & + & \\
\hline & & H. livingstoni & Livingstoni & + & \\
\hline & & H. morii & Blue Lumphead & + & \\
\hline & & H. polystigma & Polystigma Cichlid & + & \\
\hline & & H. venustus & Venustus Hap & & \\
\hline & Hemichromis & H. bimaculatus & Jewel Cichlid & + & \\
\hline & & H. elongates & Elongat Hemichromis & + & \\
\hline & & H. paynei & Faded Jewel Cichlid & + & \\
\hline & Heros & H. severus & Severum & + & \\
\hline & Julidochromis & L. carulius & Yellow Morph Cichlid & & \\
\hline & & J. dickfeldi & Dickfeldi Cichlid & & + \\
\hline & & J. malieri & Julidochromis albino & & \\
\hline & & J. ornatus & Ornate Julie & + & \\
\hline & & J. transcriptus & Masked Julie & + & \\
\hline & Labidochromis & L. sp. & Banded Labido & + & \\
\hline & Lamprologus & L. brichardi & Brichardi & + & \\
\hline & & L. calvus & Pearly Lamprologus & + & \\
\hline & & L. compreciceps & Compresciceps & + & \\
\hline & & L. multifasciatus & Banded Dwarf Lamprologus & + & \\
\hline & & L. silindricus & Silindricus Lamprologus & & \\
\hline & Leptosoma & L. malasa & M alasa Leptosoma & + & \\
\hline & Melanochromis & M. auratus & Auratus & + & \\
\hline & & M. johani & Johani Mbuna & + & \\
\hline & Metriaclima & M. lombardoi & Kenyi M buna Cichlid & + & \\
\hline & Metynnis & M. hypsauchen & Plain Pacu/Silver Dollar & + & \\
\hline & & M. maculatus & Red-bellied pacu & + & \\
\hline & Microgeophagus & M. ramirezi & Ramirezi & + & \\
\hline & Neolamprologus & N. brichardi & Brichardi Cichlid & + & \\
\hline & & N. cylindricus & Tanganyikan Cichlid & + & \\
\hline & & N. leleupi & Leleupi /Lemon Cichlid & + & \\
\hline & & N. microlepis & Microlepis Cichlid & + & \\
\hline & Nimbochromis & $\mathrm{N}$. venustus & Venustus Cichlid & + & \\
\hline & Papiliochromis & P. altispinosa & Bolivian Ram Cichlid & + & \\
\hline & Paretroplus & P. menarambo & M adagaskar Cichlid & + & \\
\hline & Pelvicachromis & P. pulcher & Krisbensis & + & \\
\hline & & P. taeniatus & Striped Kribensis & + & \\
\hline & Petrochromis & P. trewavasae & Trewava's Petrochromis & + & \\
\hline & Pseudotropius & $\begin{array}{l}\text { Pseudotropeus sp. } \\
\text { P. zebra }\end{array}$ & $\begin{array}{l}\text { Red Eye Tangarine Cichlid } \\
\text { Zebra/Blue Cichlid }\end{array}$ & + & \\
\hline & Pterophyllum & P. scalare & Angel Fish & + & \\
\hline & Satanoperca & S. leucosticte/jurupari & Pealy Eartheater/Jurupari & + & \\
\hline & Steatocranus & S. casuarius & Lionhead Cichlid & + & \\
\hline & Symphysodon & S. discus & Discus & + & \\
\hline & Tilapia & T. butikoferi & Buticoferi Tilapia & + & \\
\hline & & T. mariae & Tiger Tilapia & + & \\
\hline & Tropeus & T. annectens & Annectens Cichlid & + & \\
\hline & & T. duboisi & Duboisi Tropeus & + & \\
\hline
\end{tabular}


Lanjutan Lampiran 2

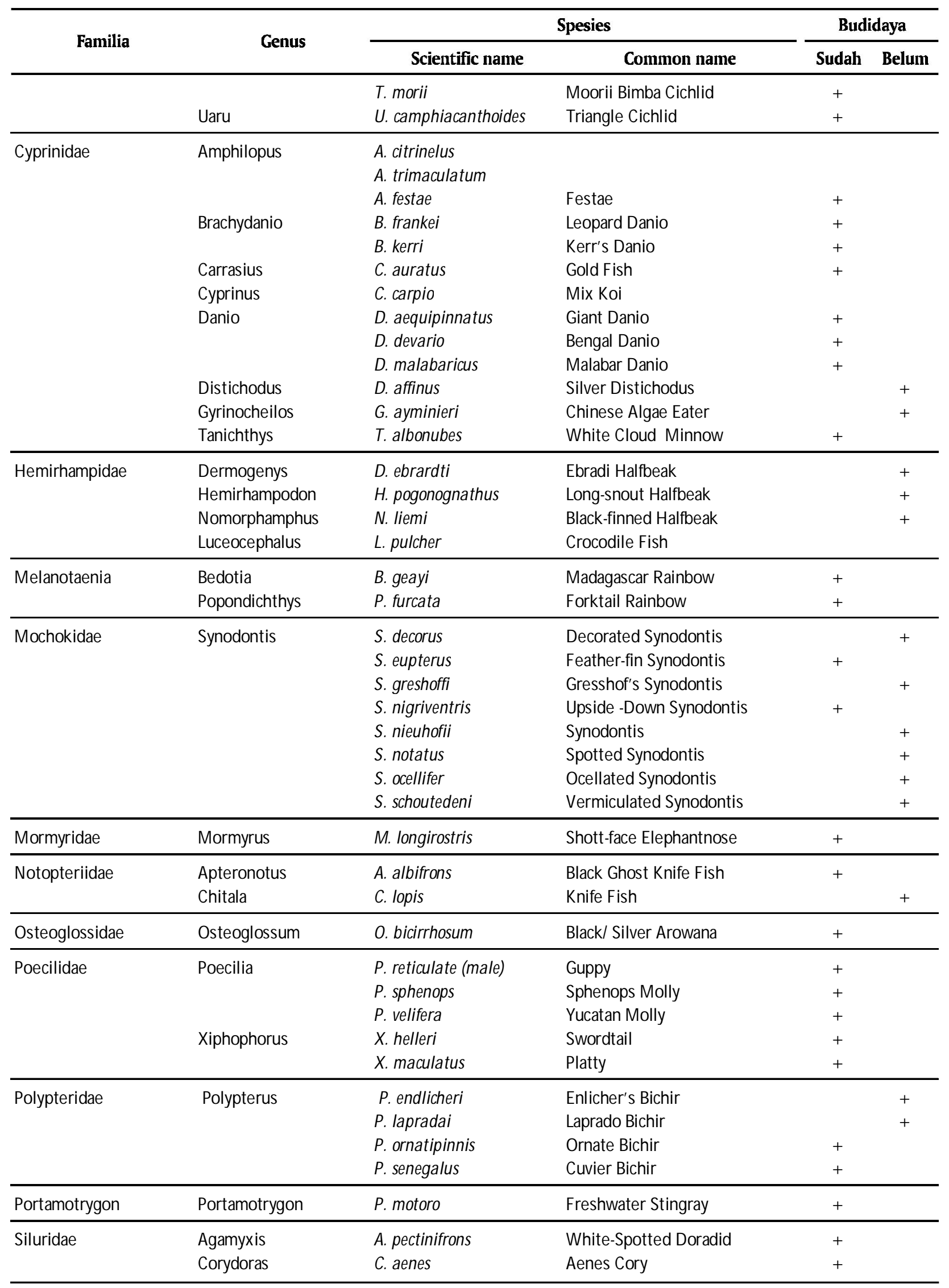


Lanjutan Lampiran 2

\begin{tabular}{|c|c|c|c|c|c|}
\hline \multirow{2}{*}{ Familia } & \multirow{2}{*}{ Genus } & \multicolumn{2}{|r|}{ Spesies } & \multicolumn{2}{|c|}{ Budidaya } \\
\hline & & Scientific name & Common name & Sudah & Belum \\
\hline & & C. adolfoi & Adolfo's Cory & + & \\
\hline & & C. amapaensis & Amapaensis Cory & + & \\
\hline & & C. julii & Julii Cory & + & \\
\hline & & C. barbatus & Filigree Cory & + & \\
\hline & & C. paleatus & Peppered Cory & + & \\
\hline & & C. metae & Bandit Cory & & + \\
\hline & & C. panda & Panda Cory & & \\
\hline & & C. pygmaeus & Pygmy Cory & + & \\
\hline & & C. rabauti & Rabaut's Cory & & + \\
\hline & & C. septentrionalis & Southern Green Cory & + & \\
\hline & & C. sterbai & Maze/Sterbai Cory & + & \\
\hline & & C. similis & Similis Cory & + & \\
\hline & Ephalzeorhynchus & E. bicolor & Red Tail Black Shark & & \\
\hline & & E. frenatus & Red-finned Shark & + & \\
\hline & Pelteobagrus & P. ornatus & Ornatus Shark & & + \\
\hline & Perrunichthys & P. perruno & Reticulated Pimelodid & & + \\
\hline & Phractocephalus & P. hemioliopterus & Redtail catfish & & + \\
\hline & & $\begin{array}{l}\text { P. hemiliopterusx } \\
\text { P. fascistus }\end{array}$ & Leopard Catfish & + & \\
\hline & Pseudopimelodus & P. zungaro & Zungaro Catfish & & + \\
\hline & Pseudoplatysoma & P. fasciatus & Tiger Catfish & + & \\
\hline & Rineloricaria & R. fallax & Delicate Whiptail Catfish & & + \\
\hline & & R. hasemani & Haseman's W hiptail Catfish & & + \\
\hline & & R. microlepidogaster & Small-scale Whiptail Catfish & & + \\
\hline & & R. similima & Similima Catfish & & + \\
\hline & Sturisoma & S. parahictysleightoni & Leightoni Catfish & & + \\
\hline & & S. panamense & Farlowella Royal Catfish & & \\
\hline & & S. pursochi & Pusoch's Catfish & & \\
\hline \multicolumn{6}{|c|}{ SPESIES NON IKAN } \\
\hline \multirow[t]{7}{*}{ Amphibia } & Hymenochirus & H. boettgeri & Amphibian Frog & & + \\
\hline & Litora & L. caerulia & Tree White Frog & & + \\
\hline & & L. infrafrenata & Tree Giant Green Frog & & + \\
\hline & Megophrys & M. nasuta & Horned borneo Frog & & + \\
\hline & Polypedates & P. otilohus & Tree W hite Gliding Frog & & + \\
\hline & Rana & R. raniceps & Amphibian Frog & & + \\
\hline & Xonopus & X. laevis & Clawed W hite Frog & & + \\
\hline \multirow[t]{2}{*}{ Crustacea } & Neocaridina/Caridina & Caridina sp. & Crystal Red Bee Shrimp. & + & \\
\hline & Cambarelus & C. patwarensis & Mini Mexican Lobster & & + \\
\hline
\end{tabular}

